\title{
RISK MODELLING OF SHALE GAS DEVELOPMENT SCENARIOS IN THE CENTRAL KAROO
}

\author{
GREGORY O. SCHREINER ${ }^{1,2}$ \& LUANITA SNYMAN-VAN DER WALT ${ }^{2, *}$ \\ ${ }^{1}$ University of the Witwatersrand, South Africa. \\ ${ }^{2}$ Council for Scientific and Industrial Research, South Africa. \\ *ORCID: http://orcid.org/0000-0002-0757-9102
}

\begin{abstract}
The scientific assessment of shale gas development was compiled by over 200 authors and peer reviewers from around the world. Novel methods of assessment were used, based on the concepts of scenarios, risk and predictive landscape modelling. Three development scenarios were assessed against a baseline scenario, across 17 topic-specific chapters. Risk profiles for spatially explicit impacts in distinctive receiving environments were generated and investigated with and without mitigation. Risk was determined by simultaneously considering the consequence of an impact and its likelihood of occurrence, with topicconsequence terms calibrated to ensure a degree of consistency across all topics. A landscape risk model was populated to generate a composite spatial overlay representing the cumulative evolution of the risk profile across the scenarios, representing the full lifecycle of shale gas development activities from initial exploration to final closure and site remediation. For the production-scale scenarios, risk ranges from very high and high before mitigation; to generally moderate after mitigation, assuming that best-practice mitigation is applied and that adequate governance and institutional capacity exists to enforce it. Given the expanse of the study area $\left(171811 \mathrm{~km}^{2}\right)$ and the relatively small physical surface footprint of shale gas development activities, mitigation best practice is led through application of the mitigation hierarchy, prescribing avoidance of impacts first, largely by adjusting the exact location of wellpads, roads and other structures to not coincide with sensitive surface and geophysical features. Through effective project planning, the majority of sensitive environments in the Central Karoo can be avoided, thus maintaining the social and ecological character and integrity of the region which is so important to many stakeholders. From a cumulative risk perspective, modelling results suggest that shale gas development activities, at the scale expected in the large-scale gas production scenario, may be near to exceeding the development threshold of the Central Karoo given the current paucity of water, skills and infrastructure in the region. Keywords: avoidance, hydraulic fracturing, landscape modelling, risk, scenarios, scientific assessment, shale gas development, thresholds
\end{abstract}

\section{INTRODUCTION}

Experience from around the world with shale gas exploration and production (collectively termed 'development') has revealed some potential negative impacts. For instance, there is evidence of the presence of gas in surface aquifers from deep sources following hydraulic fracturing [1], and methane leakage during the extraction and transportation of gas which significantly reduces climate-change benefits [2]. Surface disturbances associated with activities in and around production wellpads such as road construction and increased traffic [3], water and waste management; and associated gas transport and utilisation infrastructure [4] are not negligible. Neither are the sensory impacts in what were often previously non-industrial environments and the unintended socio-economic impacts of attracting non-local workers into formerly rural communities, the so-called 'boomtown' phenomenon [5].

The shale gas energy revolution in the United States has offered insights into the opportunities and risks associated with the impacts typical of the shale gas development lifecycle and the ramifications of an industry or technology outpacing research, regulation and governance [6]. Elsewhere in the world, countries with shale gas potential have taken a more cautious approach to shale gas development [7], the decision assisted in part by global economic recession and the low price of oil. South Africa has followed a similar cautionary trajectory, 
with government making a commitment to a step-wise approach to augmenting and amending the existing regulatory regime prior to shale gas development at any significant scale.

Even so, shale gas development in South Africa remains a contested issue. There is high uncertainty regarding both the distribution and magnitude of gas reserves [8] and the potential social and ecological consequences in a country which lacks experience with a gas infrastructure. Since 2010, when the intention to explore for shale gas in the Central Karoo was first mooted, shale gas development has been a highly divisive issue, but one which was, until now, poorly informed by publically available evidence. The national discourse has been framed, as it has in many other parts of the world, as a polarised opposition between those promoting economic and energy security benefits versus those who believe that any kind of shale gas development will have unacceptable consequences [9].

To address this lack of critically evaluated information, South African government commissioned an independent scientific assessment in February 2015, the content of which was released formally to the stakeholders and scientific community in November 2016 [10]. Three national science councils led the assessment, with contributions from 146 independent authors and 75 national and international peer reviewers covering 17 topics. The topics, drafted as peer-reviewed assessment chapters, included: energy planning [11], air quality and greenhouse gas emissions [12], earthquakes [13], surface water and groundwater resources [14], waste management and planning [15], biodiversity and ecosystems services [16], agriculture [17], tourism [18], economics [19]), social fabric [20], human health [21], 'sense of place' values [22], visual and scenic resources [23], heritage features [24], noise [25] electromagnetic interference with radio astronomy [26] and municipal infrastructure and service planning [27], within a $171811 \mathrm{~km}^{2}$ study area of the Central Karoo (Fig. 2).

In order to deliver the process and methods capable of addressing all the questions most important to society in a trusted and credible manner, an elaborate scientific assessment was co-designed with assessment participants. Process innovations with respect to previous assessments conducted in South Africa included highly inclusive and transparent procedures for content generation; deliberately diverse multi-author topic teams in place of single expert authors; three transparent peer and stakeholder review loops in place of the usual single, opaque review processes; integrated project governance structures; multiple public outreach fora in place of the usual fractious 'town hall' complaint sessions; and engagement rather than exclusion of the media. These process steps are captured, in a generic sense, in Scholes et al. [28] and more specifically, as they relate to the shale gas scientific assessment, in Schreiner et al. [29]. Method innovations included the co-generation of multiple development scenarios which were assessed within a structured and transparent expert judgement process, rooted in a shared concept of risk. The calibrated and consistent nature of the risk assessment, which was undertaken in a spatially explicit manner, meant that risk could be overlaid across topics and modelled across the scenarios showing spatial and temporal range, plus an evolving risk profile pre- and post-mitigation. The purpose of this paper is to provide a summary of these key methods and communicate the most salient risk findings, as they relate to shale gas development thresholds and best-practice mitigation.

\section{SCENARIOS FOR ASSESSMENT}

Scenarios serve various purposes. Some support scientific research processes, while others underpin assessment processes, strategic planning and decision-making [30]. Framing the spatial and temporal dynamics of a future as a plausible scenario reduces uncertainty and allows for analysis of social and ecological consequences driven by local, regional and global 
changes [31]. While scenarios are predicated on the assumption that the future is fundamentally unpredictable [32], they do acknowledge that complexity and uncertainty can be constrained to within logical limits [30] so that reasonable, relevant and alternate stories about the future can be co-generated and assessed [33].

The way scenarios are applied varies from context to context. Generally, three 'dimensions' must be considered: (i) the relevant sustainability issues; (ii) the spatial scale of the receiving environment; and (iii) the duration of the impacts being assessed [34]. This information, triangulated through a logical narrative with corresponding quantitative (numerical) data, provides the basis upon which an assessment can be made. Scenarios developed in the shale gas scientific assessment followed an incremental approach which had two main stages. The first involved identifying the major concerns as expressed by stakeholders. The second stage was to determine the key uncertainties. The major concerns related to the levels of risk associated with increasing shale gas development activities within the Central Karoo and the key uncertainty related to the volumes of economically recoverable gas reserves present in the shale deposits of the Karoo Basin [8].

Table 1: A condensed summary of the three development scenarios and numerical value estimates for key impact drivers, calculated over the entire lifecycle of the scenario (after [8]). All scenarios occur 'on-top' of and including the reference scenario (S0), a nonstationary baseline which assumed ongoing urbanisation in the Central Karoo and a shift over the next half century from largely agricultural activities to a mixed economy of farming, tourism, renewable energy and scientific research (the region is host to a large international astrophysical research project called the Square Kilometre Array).

\begin{tabular}{|c|c|c|c|}
\hline Scenario & S1 & $\mathbf{S} 2$ & S3 \\
\hline Summary narrative/units & $\begin{array}{l}\text { Exploration } \\
\text { proceeds, } \\
2018-2025\end{array}$ & $\begin{array}{l}\text { Small scale } \\
\text { production } \\
\text { follows S1, } \\
2025-2040\end{array}$ & $\begin{array}{l}\text { Large scale } \\
\text { production } \\
\text { follows S2, } \\
2040-2055\end{array}$ \\
\hline $\begin{array}{l}\text { Trillion cubic feet (tcf) of economically } \\
\text { recoverable gas in the study area }\end{array}$ & 0 & 5 & 20 \\
\hline Production block/s [30 × $30 \mathrm{~km}$ wellfield] & 0 & 1 & 4 \\
\hline Combined cycle gas turbine [1 $000 \mathrm{MW}]$ & 0 & 1 & 0 \\
\hline Combined cycle gas turbine [2 $000 \mathrm{MW}$ ] & 0 & 0 & 2 \\
\hline Gas-to-liquid plant [65 000 barrels/day] & 0 & 0 & 1 \\
\hline Number of wellpads [2 ha each] & 30 & 55 & 410 \\
\hline New roads (km), [unpaved, $5 \mathrm{~m}$ wide] & 30 & 58 & 235 \\
\hline Total area of wellpads and new roads (ha) & 75 & 199 & 998 \\
\hline Percentage spatial coverage of study area & $<0.0001$ & 0.0002 & 0.0009 \\
\hline Total number of truck visits & 45000 & 365000 & 2177000 \\
\hline Industry water needs $\left(\mathrm{m}^{3}\right),[50 \%$ reuse $]$ & 319110 & 6056160 & 43087235 \\
\hline Flowback waste $\left(\mathrm{m}^{3}\right)$ & 101400 & 5573900 & 40356400 \\
\hline Other hazardous waste (t) [e.g. oil, grease] & 85 & 635 & 3185 \\
\hline
\end{tabular}


Three development scenarios: 'Exploration Only' (S1), 'Small Gas' (S2) and 'Big Gas' (S3), were produced in relation to a Reference Case (S0), where no shale gas exploration occurs but other changes proceed (Table 1). The scenarios were co-designed through collaborative processes of engagement workshops consisting of experts from the oil and gas industry, petroleum geologists, engineers, energy planners; and natural and social scientists. Qualitative information was presented as narrative descriptions of future developments in the form of storylines and images. These formed the basis for numerical estimates of key parameters of future development (such as volumes of economically recoverable gas reserves, number of wellpads, kilometres of road, litres of water used and so on) presented as tables, graphs and maps [35]. The first draft of the scenarios (see [8]) was submitted for national and international peer review followed by general stakeholder review with a traceable comments and responses record. Following finalisation, the scenarios formed the common basis upon which the 17 topic-specific chapters undertook their respective structured risk assessments.

\section{RISK-ASSESSMENT APPROACH}

The risk-assessment approach was loosely based on that of the Fifth Assessment Report of the United Nations Intergovernmental Panel on Climate Change [36]. Risk was conceptually

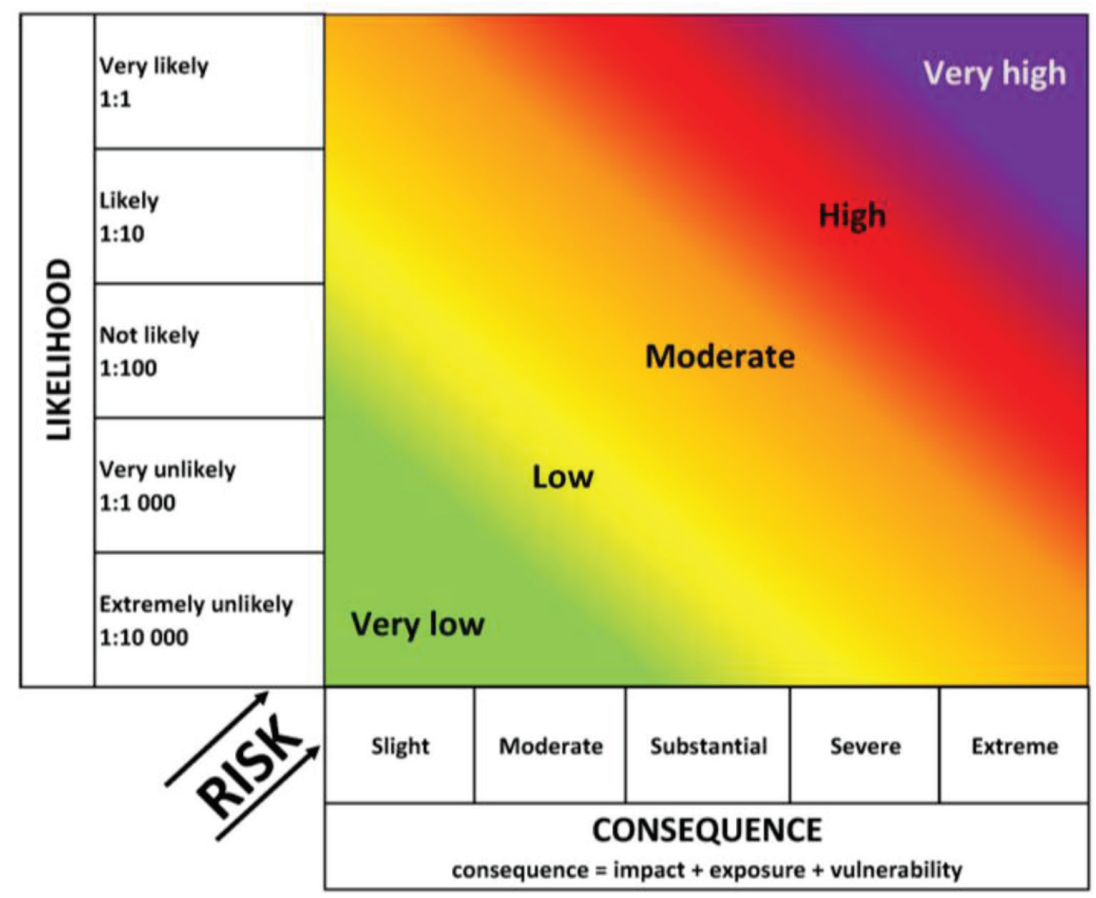

Figure 1: Likelihood was estimated qualitatively against a common framework of probability ranging from extremely unlikely to very likely (after [37]). Consequence was determined by considering the nature of an impact, the level of exposure of an entity to that impact and the vulnerability of the receiving environment or entity. It was recognised that unlikely impacts of extreme or severe consequence can be just as 'risky' as those with higher likelihood of occurrence but lower consequences per impact. 
framed by considering the consequence of an impact and the likelihood of its occurrence. Consequence was determined by considering the nature of an impact, the exposure of the reiving environment to the impact and the vulnerability of the receiving environment (Fig. 1). Impact was defined as a natural or human-induced physical event or trend that may cause loss of life, injury, or other health impacts, as well as damage and loss to property, infrastructure, livelihoods, service provision, ecosystems and environmental resources. Exposure referred to the presence of people, livelihoods, species, ecosystems, environmental functions, services, and resources, infrastructure, or economic, social, or cultural assets in places and settings that could be adversely affected. Vulnerability referred the propensity or predisposition to be adversely affected. Vulnerability encompassed a variety of concepts and elements including sensitivity or susceptibility to harm and lack of capacity to cope and adapt [36].

In order to ensure consistency, the consequences terms (Fig. 1), ranging from slight to extreme, were calibrated for each topic. For example, for an impact to biodiversity and ecosystem services, slight meant ' $20 \%$ physical loss of a near threatened biodiversity habitat', while extreme meant ' $80 \%$ loss of the same habitat'. Slight for an impact like air quality on human health meant 'no adverse long-term health effects', while extreme meant 'significant injury likely to result in death'. The consequence calibration exercise was undertaken for all 17 topics. This ensured reliability in the manner in which risks were measured, enabled integration across different topic disciplines and provided a common conceptual understanding and spatial interpretation of risk. Risk was assessed for each significant impact, on each different type of receiving environment, qualitatively (very low, low, moderate, high, very high) against a predefined set of criteria (Table 2) [28].

Risks were assessed 'with' and 'without mitigation', across the three development scenarios and in relation to S0. 'Without mitigation' assumed inadequate governance capacity,

Table 2: Summarised definitions of predefined criteria for risk classes applied across all the topics of the scientific assessment (after [37]).

\section{Risk category Definition}

$\begin{array}{ll}\text { Very low risk } & \begin{array}{l}\text { Extremely unlikely of having a consequence of any discernible magni- } \\ \text { tude; well within tolerance and adaptive capacity. }\end{array} \\ \text { Low risk } & \begin{array}{l}\text { Very unlikely to have more than a moderate consequence; limited in } \\ \text { spatial extent, of short duration ( }<3 \text { years) and with limited effect on } \\ \text { resources or attributes. }\end{array} \\ \text { Moderate risk } & \begin{array}{l}\text { Not unlikely, or if more likely than this, then the consequences are sub- } \\ \text { stantial and could be persistent (3-5 years) but less than severe because } \\ \text { it is well below limits of acceptable change. }\end{array} \\ \text { High risk } & \begin{array}{l}\text { Likely of having a severe and persistent }(>5 \text { years) consequence where } \\ \text { there may be an affordable and accessible substitute, but which is less } \\ \text { acceptable. Approaching the limit of acceptable change. }\end{array} \\ \text { Very high risk } & \begin{array}{l}\text { Highly likely to have an extremely negative and very persistent conse- } \\ \text { quence ( }>20 \text { years). Greater than the limit of acceptable change for an } \\ \text { important resource for which there is no alternative. }\end{array}\end{array}$


weak decision-making and non-compliance with regulatory requirements. 'With mitigation' assumed effective implementation of best-practice principles, adequate institutional governance capacity and responsible decision-making. The assessment of the scenarios, both with and without mitigation led to an explicit difference between the assessed outcomes which provides decision-makers with practical estimation of the importance of strong governance and institutional functionality when managing shale gas development.

\section{RESULTS OF THE RISK ASSESSMENT}

Following the results of the structured risk assessment, undertaken for the 17 topics, the following impacts were considered to have either a very high or high risk before mitigation; or alternatively, had a moderate risk even after mitigation applied (the level of risk assessed after mitigation is provided in parentheses):

1. Energy infrastructure that does not match domestic shale gas supply and the availability of sufficient network capacity to evacuate electricity (moderate-low risk after mitigation for S2 and S3) [11];

2. Exposure to air pollutants from flaring, dust and other activities that diminish air quality (moderate risk after mitigation for S1, S2 and S3) [12];

3. Fugitive greenhouse gas emissions from production wellpads and supporting gas infrastructure (moderate risk after mitigation for S3) [12];

4. Occurrence of earthquakes (magnitude $>5$ ) causing damage to heritage resources and human health (moderate risk after mitigation for S3 within $20 \mathrm{~km}$ of towns) [13];

5. Reduced surface- and groundwater availability for people and other economic activities (high risk after mitigation for S2 and S3) [14];

6. Contamination of groundwater resources caused by a loss of well integrity and via preferential geological pathways (moderate risk after mitigation for S2 and S3) [14];

7. Physical disturbance of watercourses during the construction phase (moderate risk after mitigation for S2 and S3 in regions of high aquatic sensitivity) [14];

8. Contamination of surface water as a result of flowback discharge or as a result of contact with contaminated groundwater (moderate risk after mitigation for S2 and S3 in regions of high aquatic sensitivity) [14];

9. Human exposure to waste and additional sewage loads caused by increased development activities (low risk after mitigation for S2 and S3) [15];

10. Impacts on biodiversity and ecological processes (moderate risk after mitigation for $\mathrm{S} 2$ and S3 in regions of high biodiversity sensitivity) [16];

11. Impacts on farming and agriculture (moderate-high risk after mitigation for S2 and S3 in regions of high agricultural sensitivity) [17];

12. Reduction in tourists, enterprises and financial losses to the rural economy (moderatehigh risk after mitigation for S2 and S3 in regions of high tourism sensitivity) [18];

13. Impacts to public finances of externality costs and reduced property values (moderate risk after mitigation for S3) [19];

14. Human in-migration, altered physical security and new power dynamics (moderate-high risk after mitigation for S1, S2 and S3) [20];

15. Reduced human health through exposure to contaminated water and air (moderate risk after mitigation for S2 and S3) [21];

16. Worker physical injury through contact with traffic or machinery (moderate risk after mitigation for S2 and S3) [21]; 
17. Loss of 'sense of place' for people who live in or value the Central Karoo (moderate-high after mitigation for S0, S1, S2 and S3) [22];

18. Visual intrusion of activities into the landscape (moderate-high risk after mitigation for S2 and S3 in regions of high visual sensitivity) [23];

19. Impacts on built heritage, archaeology and cultural landscapes (low-high risk after mitigation for S1, S2 and S3 in regions of high heritage sensitivity [24];

20. Noise disturbance to humans and animals (moderate to high risk after mitigation for S2 and S3 within $5 \mathrm{~km}$ of wellpads) [25];

21. Electromagnetic interference with radio astronomy (very low-moderate risk after mitigation for S2 and S3 in high sensitivity electromagnetic zones) [26]; and

22. Local road construction and pressure on municipal service infrastructure (moderate risk after mitigation for S2 and S3) [27].

The impacts and associated risk profiles expressed within spatially distinguishable and mapped receiving environments (impacts: $2,4,6,7,8,10,11,12,18,19,21$ ) were plotted into a spatially explicit risk model which considered S1, S2 and S3 in relation to S0. Layers of risk, expressive of the materialisation of impacts in the spatially distinguishable regions were overlaid and depicted using the 'maximum rule' to prioritise the highest risk regions over those of lower risk (Fig. 2). The purpose of the risk modelling exercise was to demonstrate the evolution of the risk profile across the scenarios considered, which accounts for the full lifecycle of shale gas development activities, and to test the efficacy of mitigation actions in reducing cumulative risk and identifying landscape thresholds across temporal range.

S1 assumed extensive seismic surveys plus vertical and horizontal drilling from 30 exploration wellpads with hydraulic fracturing which equated to less than $0.0001 \%$ of the study area being directly affected by shale gas development activities. At the strategic level of assessment, the model indicates that the spatial risks associated with $\mathrm{S} 1$ could be mitigated to low-moderate. For S2 and S3, while only a fraction ( $0.0002 \%$ and $0.0009 \%$ respectively) of the study area will be directly impacted, the risk profile does increase because of indirect and cumulative impacts. With mitigation, S2 shows mosaics of low and moderate risk scattered through the study area, with the eastern highlands dominated by sensitive landscapes characterised by denser distribution of rural communities [8], diverse habitats and greater concentrations of protected areas [16], higher agricultural production potential [17], and an increased concentration of scenic resources and landscapes [23]. There are sizeable regions of moderate risk located in or around the central regions of the study area, which is considered the most prospective for shale gas [8].

As defined at the outset of the risk assessment and modelling process, high risk is considered to mean a risk that is 'approaching the limit of acceptable change' [37]. The risk modelling indicates that as shale gas development increases beyond S2, as do the magnitude and intensity of ancillary development activities and hence the $\mathrm{S} 3$ risk profile becomes more dominated by high risk regions and fewer regions of moderate and low risk, even after mitigation is applied [8]. This threshold should be borne in mind as a strategic approach to adaptive risk management and should serve as a marker that encourages the scientific community, developers, stakeholders and decision-makers to stop and reassess the state of evidence and the assumptions that underpinned previous decisions as they regard shale gas development. 


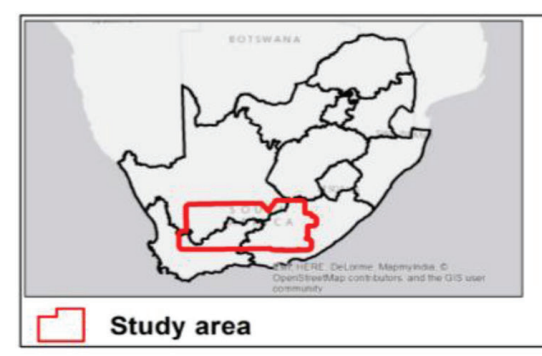

Without mitigation
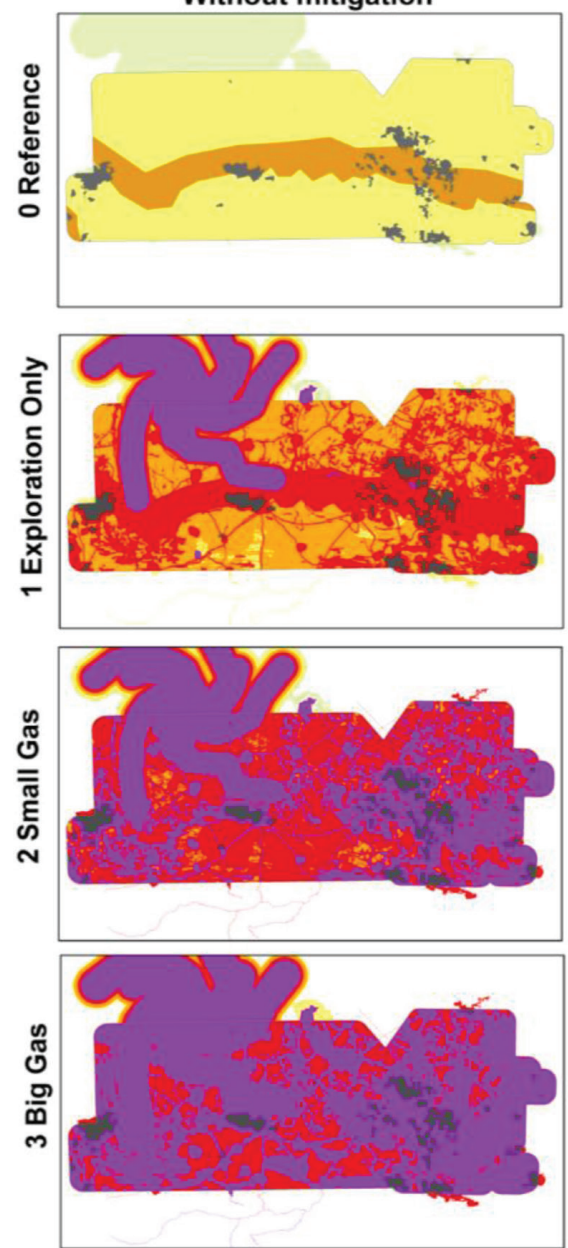

Composite risk of shale gas development RISK

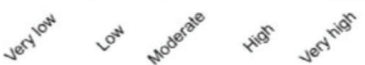

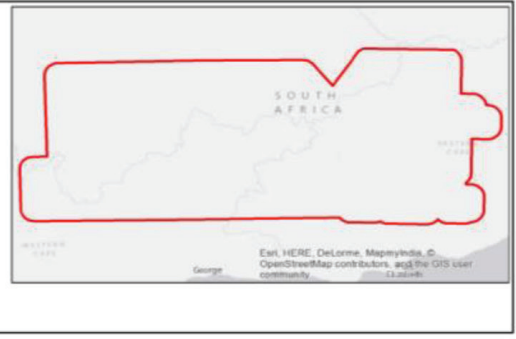

With mitigation
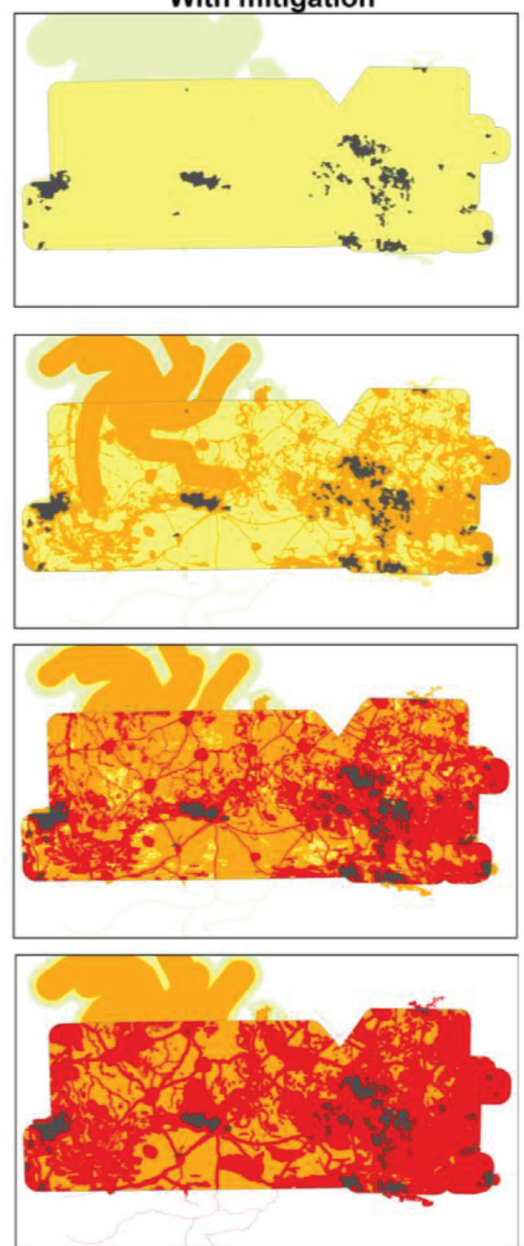

$\begin{array}{lllll}N & 0 & 125 & 250 & 500 \mathrm{~km}\end{array}$

Figure 2: Spatially explicit risk profiles within the $171811 \mathrm{~km}^{2}$ study area of the Central Karoo, depicting the risk of shale gas development across four scenarios with and without mitigation applied (Source: [37]). 


\section{CONCLUSION}

Very little infrastructure currently exists in the Central Karoo to support a domestic gas industry $[7,14,15,27]$. As such, new roads, waste handling and treatment facilities, pipelines, gas combustors and powerlines would need to be constructed for S2 and S3 [8]. Considering that no established gas infrastructure currently exists and that there is a high degree of flexibility in wellpad positioning, supported by advances in horizontal drilling technologies, there is scope for integrated and strategic planning, prior to development, to reduce associated risk [37]. Shale gas development through hydraulic fracturing at great depth provides a considerable degree of flexibility in the exact siting of the surface infrastructure, which means that there is high potential for risk reduction through application of the 'mitigation hierarchy', which promotes avoidance first.

Through effective project planning, many sensitive features of the Central Karoo can be avoided altogether, thus maintaining the social and ecological character and integrity of the region. Sensitive features which should be avoided include surface water and groundwater resources [14], regions of active seismicity [13], biodiversity and ecological hotspots [16], high potential agricultural land [17], heritage resources and features [24], important tourism areas or routes [18], vulnerable people living in towns or rural communities [20], high sensitivity visual resources [23] and the footprint of the South African mid-frequency radio astronomy project, the Square Kilometre Array [26].

In accordance with existing South African environmental legislation [38], shale gas development would be guided through all the potential futures by mandatory site-specific Environmental Impact Assessments (EIAs) which should prescribe the implementation of adequate mitigation, primarily through avoidance, and the monitoring requirements prior to, during and following closure of development sites. This will, among other technical constraints [7], result in the mitigation of rapid, unplanned and sprawling growth of the shale gas industry in the Central Karoo.

\section{ACKOWLEDGEMENTS}

The authors would like to acknowledge over 200 authors and peer reviewers responsible for the development of material leading to the finalisation of scientific assessment for shale gas development. The scientific assessment was funded by the national Department of Environmental Affairs. Prof Bob Scholes, who co-led the assessment, provided invaluable inputs into first drafts of this paper. GOS was coordinator of the overarching scientific assessment process and acted as lead-author of this paper. LSVDW led the mapping and modelling component of the scientific assessment and provided detailed inputs into this paper regarding the key steps and outputs from that process.

\section{REFERENCES}

[1] Vengosh, A., Jackson, R.B., Warner, N., Darrah T.H. \& Kondash, A., A critical review of the risks to water resources from unconventional shale gas development and hydraulic fracturing in the United States. Environmental Science \& Technology, 48(15), pp. 8334-8348, 2014. https://doi.org/10.1021/es405118y

[2] Bradbury, J., Obeiter, M., Draucker, L., Wang, W. \& Stevens, A.M., Clearing the air: Reducing upstream greenhouse gas emissions from US natural gas systems. World Resources Institute, 2013.

[3] Drohan, P.J., Brittingham, M., Bishop, J. \& Yoder, K., Early trends in landcover change and forest fragmentation due to shale-gas development in Pennsylvania: a potential outcome for the Northcentral Appalachians. Environmental Management, 49(5), pp. 1061-1075, 2012. https://doi.org/ 10.1007/s00267-012-9841-6 
[4] Ziemkiewicz, P.F., Quaranta, J.D., Darnell, A. \& Wise, R. Exposure pathways related to shale gas development and procedures for reducing environmental and public risk. Journal of Natural Gas Science and Engineering, 16, pp. 77-84, 2014. https://doi.org/ 10.1016/j.jngse.2013.11.003

[5] Christopherson, S. \& Rightor, N. 2011. How shale gas extraction affects drilling localities: lessons for regional and city policy makers. Journal of Town \& City Management, 2(4), pp. 350-368, 2011.

[6] Small, M.J., Stern, P.C., Bomberg, E., Christopherson, S.M., Goldstein, B.D., Israel, A.L., Jackson, R.B., Krupnick, A., Mauter, M.S., Nash, J. \& North, D.W., Risks and risk governance in unconventional shale gas development. Environmental Science \& Technology, 48, pp. 8289-8297, 2014.

https://doi.org/ 10.1021/es502111u

[7] Academy of Science of South Africa (ASSAf). South Africa's technical readiness to support the shale gas industry. Pretoria: ASSAf, 2016.

https://doi.org/ 10.17159/assaf.2016/0003

[8] Burns, M., Atkinson, D., Barker, O., Davis, C., Day, L., Dunlop, A., Esterhuyse, S., Hobbs, P., McLachlan, I., Neethling, H., Rossouw, N., Todd, S., Snyman-Van der Walt, L., Van Huyssteen, E., Adams, S., de Jager, M., Mowzer, Z. \& Scholes, B., Scenarios and activities. shale gas development in the central karoo: a scientific assessment of the opportunities and risks, ed. Scholes, R., Lochner, P., Schreiner, G., Snyman-Van der Walt, L. and de Jager, M. Pretoria: CSIR, 2016. ISBN: 978-0-7988-5631-7.

[9] De Wit, M.J. The great shale debate in the Karoo. South African Journal of Science, 107(7-8), pp. 2-10, 2011.

https://doi.org/10.4102/sajs.v107i7/8.791

[10] CSIR., Strategic environmental assessment for shale gas development. Available at: http://seasgd.csir.co.za/

[11] Wright, J., Bischof-Niemz, T., Carter-Brown, C. \& Zinaman, O., Effects on national energy planning and energy security. shale gas development in the central karoo: a scientific assessment of the opportunities and risks, ed. Scholes, R., Lochner, P., Schreiner, G., Snyman-Van der Walt, L. and de Jager, M. Pretoria: CSIR, 2016. ISBN: 978-0-7988-5631-7.

[12] Winkler, H., Altieri, K., Clarke, S., Garland, R.M., Kornelius, G., \& Meas, M., Air quality and greenhouse gas emissions. shale gas development in the central karoo: a scientific assessment of the opportunities and risks, ed. Scholes, R., Lochner, P., Schreiner, G., Snyman-Van derWalt, L. and de Jager, M. Pretoria: CSIR, 2016. ISBN: 978-0-7988-5631-7.

[13] Durrheim, R., Doucouré, M. \& Midzi, V., Earthquakes. shale gas development in the central karoo: a scientific assessment of the opportunities and risks, ed. Scholes, R., Lochner, P., Schreiner, G., Snyman-Van der Walt, L. and de Jager, M. Pretoria: CSIR, 2016. ISBN: 978-0-7988-5631-7.

[14] Hobbs, P., Day, E., Rosewarne, P., Esterhuyse, S., Schulze, R., Day, J., Ewart-Smith, J., Kemp, M., Rivers-Moore, N., Coetzee, H., Hohne, D., Maherry, A. \& Mosetsho, M., Water resources. Shale gas development in the Central Karoo: a scientific assessment of the opportunities and risks, ed. Scholes, R., Lochner, P., Schreiner, G., Snyman-Van der Walt, L. and de Jager, M. Pretoria: CSIR, 2016. ISBN: 978-0-7988-5631-7.

[15] Oelofse, S., Schoonraad, J. \& Baldwin, D., Impacts on waste planning and management. shale gas development in the central karoo: a scientific assessment of the opportunities and risks, ed. Scholes, R., Lochner, P., Schreiner, G., Snyman-Van der Walt, L. and de Jager, M. Pretoria: CSIR, 2016. ISBN: 978-0-7988-5631-7. 
[16] Holness, S., Driver, A., Todd, S., Snaddon, K., Hamer, M., Raimondo, D., Daniels, F., Alexander, G., Bazelet, C., Bills, R., Bragg, C., Branch, B., Bruyns, P., Chakona, A., Child, M., Clarke, R.V., Coetzer, A., Coetzer, W., Colville, J., Conradie, W., Dean, R., Eardley, C., Ebrahim, I., Edge, D., Gaynor, D., Gear, S., Herbert, D., Kgatla, M., Lamula, K., Leballo, G., Lyle, R., Malatji, N., Mansell, M., Mecenero, S., Midgley, J., Mlambo, M., Mtshali, H., Simaika, J., Skowno, A., Staude, H., Tolley, K., Underhill, L., van der Colff, D., van Noort, S. \& von Staden, L., Biodiversity and ecological impacts: landscape processes, ecosystems and species. shale gas development in the central karoo: a scientific assessment of the opportunities and risks, ed. Scholes, R., Lochner, P., Schreiner, G., Snyman-Van der Walt, L. and de Jager, M. Pretoria: CSIR, 2016. ISBN: 978-0-7988-5631-7.

[17] Oettle, N., Lindeque, L., du Toit, J., Samuels, I., Osler, A., Vetter, S. \& van Garderen, E.A., Impacts on agriculture. Shale gas development in the central Karoo: a scientific assessment of the opportunities and risks, ed. Scholes, R., Lochner, P., Schreiner, G., Snyman-Van der Walt, L. and de Jager, M. Pretoria: CSIR, 2016. ISBN: 978-0-7988-5631-7.

[18] Toerien, D., du Rand, G., Gelderblom, C. \& Saayman, M., Impacts on tourism in the karoo. shale gas development in the central karoo: a scientific assessment of the opportunities and risks, ed. Scholes, R., Lochner, P., Schreiner, G., Snyman-Van der Walt, L. and de Jager, M. Pretoria: CSIR, 2016. ISBN: 978-0-7988-5631-7.

[19] Van Zyl, H., Fakir, S., Leiman, T. \& Standish, B. Impacts on the Economy. shale gas development in the central Karoo: a scientific assessment of the opportunities and risks, ed. Scholes, R., Lochner, P., Schreiner, G., Snyman-Van der Walt, L. and de Jager, M. Pretoria: CSIR, 2016. ISBN: 978-0-7988-5631-7.

[20] Atkinson, D., Schenk, R., Matebesi, Z., Badenhorst, K., Umejesi, I. \& Pretorius, L., Impacts on social fabric. shale gas development in the central Karoo: a scientific assessment of the opportunities and risks, ed. Scholes, R., Lochner, P., Schreiner, G., Snyman-Van der Walt, L. and de Jager, M. Pretoria: CSIR, 2016. ISBN: 978-0-7988-5631-7.

[21] Genthe, B., Maherry, A., Steyn, M., Rother, A., London, L., \& Willems, M., Impacts on human health. Shale gas development in the Central Karoo: A scientific assessment of the opportunities and risks, ed. Scholes, R., Lochner, P., Schreiner, G., Snyman-Van der Walt, L. and de Jager, M. Pretoria: CSIR, 2016. ISBN: 978-0-7988-5631-7.

[22] Seeliger, L., de Jongh, M., Morris, D., Atkinson, D., du Toit, K. \& Minnaar, J. Impacts on sense of place. shale gas development in the central karoo: a scientific assessment of the opportunities and risks, ed. Scholes, R., Lochner, P., Schreiner, G., Snyman-Van der Walt, L. and de Jager, M. Pretoria: CSIR, 2016. ISBN: 978-0-7988-5631-7.

[23] Oberholzer, B., Lawson, Q., Klapwijk, M., Young, G., Anderson, M. \& Orton, J., Visual, aesthetic and scenic resources. shale gas development in the central Karoo: a scientific assessment of the opportunities and risks, ed. Scholes, R., Lochner, P., Schreiner, G., Snyman-Van der Walt, L. and de Jager, M. Pretoria: CSIR, 2016. ISBN: 978-0-7988-5631-7.

[24] Orton, J., Almond, J., Clarke, N., Fisher, R., Hall, S., Kramer, P., Malan, A., Maguire, J. \& Jansen, L., Impacts on heritage. shale gas development in the central karoo: a scientific assessment of the opportunities and risks, ed. Scholes, R., Lochner, P., Schreiner, G., Snyman-Van derWalt, L. and de Jager, M. Pretoria: CSIR, 2016. ISBN: 978-0-7988-5631-7. 
[25] Wade, A., Jongens, A. \& van Niekerk, W., Noise Generated by Shale Gas- Related Activities. Shale Gas Development in the Central Karoo: A Scientific Assessment of the Opportunities and Risks, ed. Scholes, R., Lochner, P., Schreiner, G., Snyman-Van der Walt, L. and de Jager, M. Pretoria: CSIR, 2016. ISBN: 978-0-7988-5631-7.

[26] Tiplady, A., van der Merwe, P. \& Otto, B., Electromagnetic Interference. Shale gas development in the Central Karoo: a scientific assessment of the opportunities and risks, ed. Scholes, R., Lochner, P., Schreiner, G., Snyman-Van der Walt, L. and de Jager, M. Pretoria: CSIR, 2016. ISBN: 978-0-7988-5631-7.

[27] Van Huyssteen, E., Green, C., Paige-Green, P., Oranje, M., Berrisford, S. \& McKelly, D., Impacts on integrated spatial and infrastructure planning. shale gas development in the Central Karoo: a scientific assessment of the opportunities and risks, ed. Scholes, R., Lochner, P., Schreiner, G., Snyman-Van der Walt, L. and de Jager, M. Pretoria: CSIR, 2016. ISBN: 978-0-7988-5631-7.

[28] Scholes, R.J., Schreiner, G.O. \& Snyman-Van der Walt, L., Scientific assessments: matching the process to the problem. Bothalia, 47(2), pp. a2144, 2017. https://doi.org/ 10.4102/abc.v47i2.2144

[29] Schreiner, G.O., Snyman-van der Walt, L., De Jager, M., Dludla, A., Lochner, P.A., Wright, J., Scholes, R.J., Atkinson, D. \& Hardcastle, P., Advancing a participatory and sciencebased approach to policy formulation for shale gas development in South Africa. Citizen and other stakeholder participation in unconventional fossil fuel land use decision-making, policy formation, regulatory practice or other governance mechanisms, ed. Whitton, J., Cotton, M. and Brasier, K. London: Routledge, In Press.

[30] Ash, N., Blancom H., Brown, C., Garcia, K., Henrichs, T., Lusas, N., Raudsepp-Hearne, C., Simpson, R.D., Scholes, R., Tomich, T.P., Vira, B. \& Zurek, M. (eds)., Ecosystem and human well-being: A manual for assessment practitioners. Washington: Island Press, 2010.

[31] Sohl, T.L. \& Sleeter, B.M. Land-use and land-cover scenarios and spatial modeling at the regional scale (No. 2012-3091). US Geological Survey, 2012.

[32] Van Der Heijden, K., Scenarios and forecasting: two perspectives. Technological Forecasting and Social Change, 65(1), pp. 31-36, 2000.

https://doi.org/10.1016/s0040-1625(99)00121-3

[33] Hunt, D.V., Lombardi, D.R., Atkinson, S., Barber, A.R., Barnes, M., Boyko, C.T., Brown, J., Bryson, J., Butler, D., Caputo, S. \& Caserio, M., Scenario archetypes: Converging rather than diverging themes. Sustainability, 4(4), pp. 740-772, 2012. https://doi.org/10.3390/su4040740

[34] Intergovernmental Platform on Biodiversity and Ecosystem Services (IPBES)., Summary for policymakers of the assessment report of the Intergovernmental Science-Policy Platform on Biodiversity and Ecosystem Services on pollinators, pollination and food production. Potts SG, Imperatriz-Fonseca VL, Ngo HT, Biesmeijer JC, Breeze TD, Dicks LV, Garibaldi LA, Hill R, Settele J, Vanbergen AJ. (eds). Bonn: Secretariat of the Intergovernmental Science-Policy Platform on Biodiversity and Ecosystem Services. 2016.

[35] Alcamo, J. \& Henrichs, T., Chapter two towards guidelines for environmental scenario analysis. Developments in Integrated Environmental Assessment, 2, pp. 13-35, 2008. https://doi.org/10.1016/s1574-101x(08)00402-x 
[36] Intergovernmental Panel on Climate Change (IPCC). Annex II: Glossary [Mach, K.J., S. Planton and C. von Stechow (eds)]. Climate Change 2014: Synthesis Report. Contribution of Working Groups I, II and III to the Fifth Assessment Report of the Intergovernmental Panel on Climate Change [Core Writing Team, R.K. Pachauri and L.A. Meyer (eds)]. Geneve: IPCC, pp. 117-130, 2014.

[37] Scholes, R., Lochner, P., Schreiner, G., Snyman-Van der Walt, L. \& de Jager, M. (eds.), Shale gas development in the Central Karoo: a scientific assessment of the opportunities and risks. CSIR/IU/021MH/EXP/2016/003/A, ISBN 978-0-7988-5631-7, Pretoria: CSIR, 2016.

[38] South Africa. National Environmental Management Act No. 107 of 1998. Pretoria: South African Government, 1998. 